\title{
Darwin's antithesis revisited - a zoosemiotic perspective on expressing emotions in animals and animal cartoon characters
}

\author{
Jason Mario Dydynski \\ Department of Semiotics \\ University of Tartu \\ Jakobi 2, 51005 Tartu, Estonia \\ e-mail: jason.mario.dydynski@ut.ee
}

\author{
Nelly Mäekivi \\ Department of Semiotics \\ University of Tartu \\ Jakobi 2, 51005 Tartu, Estonia \\ e-mail: nelly.maekivi@ut.ee
}

\begin{abstract}
In the animation and design of cartoon characters, animators have often turned to the study of biological theories and observation of human actors and animals to capture lifelike movements and emotions more successfully. Charles Darwin's principle of antithesis, as one of the principles he considered to be responsible for the expression of emotions in animals, would seem to be of distinctive importance in the development of animation. By revisiting Darwin's original idea in the context of the principles of animation formulated by Thomas and Johnston, we are able to assess its application and relevance in the expressions of emotions in cartoon animal characters. The article concentrates on the emotive function of animal social communication as outlined in zoosemiotics, while taking into account that the expressions of animal characters are directed at the viewer. The principle of antithesis, as a descriptive tool, aids us in considering the diversity of modalities used simultaneously in affective communication, and serves to explicate human interpretations of the anthropomorphic and zoomorphic projections onto the behaviour of cartoon animal characters. This paper offers insight into the potential expansion and re-evaluation of unattested principles in animation, which can be utilized by animators in the creation of more dynamic and expressive animated characters.
\end{abstract}

Keywords: Darwin; antithesis; zoosemiotics; animal characters; animation 


\section{Introduction}

It has always been an objective in animation to create compelling and emotionally expressive characters. To achieve a lifelike quality, animators often utilize the study and observation of live animals or anatomical structures (O'Neill 2008: 25-29). However, there is a noticeable tendency to caricature the animal, as "real animals cannot act or emote as broadly as animators require" (Thomas, Johnston 1981: 333). In order to address this, a set of principles to create "believable" facial expressions and bodily movement in animated characters has been established (Beck 2011; MacWilliams 2014). The principles were first explicitly stated in the chapter "The principles of animation" of Thomas and Johnston's The Illusion of Life: Disney Animation (Thomas, Johnston 1981: 47-70). The outlined principles mostly deal with designing the characters to express emotions, the development of personality, as well as capturing these elements in the form and structure of a given character. The principles were aimed at capturing a so-called "illusion of life", which largely means believability behind the transmission and expression of emotions:

Our goal with these studies is to make the audience feel the emotions of the characters, rather than appreciate them intellectually. We want our viewers not merely to enjoy the situation with a murmured, "isn't he cu-ute?" but really to feel something of what the character is feeling. (Thomas, Johnston 1981: 22)

Though not explicitly stated, clear connections can be drawn between this classic theory of animation and prominent biological theories of the early 20th century in their approach to emotions and gestures (Steinberg 2014: 288). Charles Darwin was a pioneer in discussing the evolution of outward appearance of affective states in his 1872 book Expression of Emotion in Man and Animals. He brought out three general principles which explain " $[. .$.$] most of the expressions and gestures$ involuntarily used by man and the lower animals, under the influence of various emotions and sensations" (Darwin 1872: 27). These three principles are clearly listed as "[...] the principle of serviceable associated Habits" (i.e. when a certain state of mind induces some sort of expression and when a similar - even feeble emotion is induced, then the force of habit encourages for the same expression to emerge); "[...] the principle of Antithesis" (i.e. opposite states of minds induce expressions that appear in directly opposite forms); and "[...] the principle of actions due to the constitution of the Nervous System independently from [...] Will, and independently to a certain extent of Habit" (i.e. direct action of the nervous system) (Darwin 1872: 28-29). Although Darwin considered that the 
three principles may operate together to produce a bodily expression (Darwin 1872: 82), we shall turn our attention to the principle of antithesis as a descriptive mechanism. This is due to the fact that when Darwin explained this principle, he restricted himself mainly to animals other than humans and used it to illustrate the communication of emotion, making this principle, in our view, quite compatible with the ethological zoosemiotic approach, where "[...] signification, communication and representation within and across animal species" (Maran et al. 2011: 1) are a focal point.

Already Darwin began some exploratory research as to the extension of his theories in the representation of emotion in art, particularly in the expressions of classic paintings and sculptures. He found that these pieces prioritized beauty over the expression of emotion and did not capture realistic anatomical expression:

I had hoped to derive much aid from the great masters in painting and sculpture, who are such close observers. Accordingly, I have looked at photographs and engravings of many well-known works; but, with a few exceptions, have not thus profited. The reason no doubt is, that in works of art, beauty is the chief object; and strongly contracted facial muscles destroy beauty. Painters can hardly portray suspicion, jealousy, envy, except by the aid of accessories which tell the tale; and poets use such vague and fanciful expressions as "green-eyed jealousy". (Darwin 1872: 14-15)

As our interpretation of Darwin's description of classic art and sculpture would lead us to believe, these traditional artistic genres failed to capture antithesis in their expressions. Since his time, significant technological and artistic developments, particularly the emergence of animation, have enhanced the possibility to affect audiences' emotions without human actors (Bates 1994). This argument is also shared by Thomas and Johnston when discussing the expression of emotion in classic art. They state that "[...] since that time, we have been inundated with artists' attempts to shape something in clay or stone or paint that has a life of its own [...] and in the late 1800 s new inventions seemed to make it possible" (Thomas, Johnston 1981: 13).

Along with the growth in popularity of animation, we also saw the rise of the animal character, with many of the most successful animated animal characters achieving global recognition (e.g. Mickey Mouse, Donald Duck, and Goofy) (Brockway 1989). These animal characters captured the imaginations and hearts of audiences with their expressive characterizations and can still be seen as a dominating force in modern animation today.

This raises the question as to what extent applying antithesis, as posited by Darwin, is appropriate in the context of animated animal characters. This article 
is not the first to utilize Darwinian approaches in the understanding of animal characters in animation. Film theorist Barbara Creed (2009) used Darwin's Expression of Emotion in Man and Animals in her analysis of animal characters elaborating that

[...] the screen animal is a technological figure, its meaning and significance are different from those of actual animals - it signifies far more that the "world of nature" or feelings of sympathy or protectiveness towards the animal [...]. In darwinian terms, the screen animal signifies the collapse of boundaries between human and animal [...]. (Creed 2009: 175-178)

However, in her analysis Creed does not examine the emotive expressions of these characters or the presence of antithesis, but rather focuses on the cultural impact of these characters, arguing that animal characters, or "screen animals", tend to undermine anthropocentric views of the world (Creed 2009: 174-178). While her approach offers interesting insights into film theory and cultural studies, she only establishes a casual link to Darwin's theories, and does not mention or analyse the principles themselves, which may hold importance to the field of animation as they influence how animators engage in reference in the development of characters.

The aim of this article is to find out what techniques are utilized to create an expressive function in animated characters and whether these techniques have some grounding in the principle of antithesis. To reach our goal, we set out to investigate whether opposite emotions are expressed in antithetical forms in the animation of animal characters in comparison to real animals. Thus, we will analyse whether Darwin's claim that antithesis is one of the governing principles of emotional expression still holds ground close to 150 years later, with the advancement of scientific knowledge on animal behaviour and the progress of technology (e.g. the appearance of animated movies and cartoons). We strive to determine whether we can draw parallels between general mammalian expression and the expression of animated characters to see if antithetical expressions (e.g. in body posture, movement, elicited sound) align with communicative intent and expression, or whether antithesis, as a descriptive tool, stems rather from an anthropocentric understanding of animal communication.

In our endeavour we will rely on a semiotic approach that incorporates two branches of zoosemiotics, i.e. we will juxtapose the views of ethological and anthropological zoosemiotics through the principle of antithesis. Thus, we have the possibility to consider not only animal communication (in the broadest sense), but also our representations of other species as seen in animated animal 
characters. In analysing antithesis, we emphasize the aspect of communication between animals and the rather one-way communication between animal cartoon characters and human viewers. We shall also employ the analytical potential of Uexküll's concept of umwelt (e.g. Uexküll 1982, 1992) to examine the expressions of emotion as intra- and interspecific communicative signs, and utilize a semiotic typology established by Dagmar Schmauks (2000) to investigate the communicative intent behind the creation of animated animal characters. We shall also review more recent ethological studies, i.e. research carried out after Darwin posited the principle of antithesis (which is often tied to his studies on communication) to determine the applicability of the principle of antithesis in animals. However, we do not wish to underplay the importance of Darwin himself, because we believe it to still hold true that "[...] developments in the study of animal communication stem largely from Charles Darwin” (Sebeok 1972: 64). Thus, it is his legacy we wish to scrutinize in more detail and, if possible, to extend the relevance of Darwin's theories by drawing parallels between his principle of antithesis and the principles of animation introduced in Thomas, Johnston 1981. In doing so, this research will offer insight into the foundations of animation which can aid animators in achieving a higher degree of expressive realism in character design.

\section{On the concept of emotion}

In order to draw a link between the principle of antithesis and the emotional expression of animated characters, the concept of emotion must first be dealt with. Darwin does not define the concept of emotion, and he often uses it in tandem with the concept of sensation. Only as a footnote does he refer to Herbert Spencer, stating that Spencer has "[...] drawn a clear distinction between emotions and sensations, the latter being 'generated in our corporeal framework" (Darwin 1872: 27), without any indication as to an explanation of emotion. To complicate the matter even further, Darwin often employs the concept of feeling as synonymous to emotion and frequently refers to emotions as mental states. It must be stated that Darwin is not the only one who takes the term 'emotion' to be self-explanatory, especially when it comes to describing the expressions of other animals besides humans. Within the relevant literature on animal behaviour and communication there are plenty of instances where even contemporary authors, while discussing emotions in animals, do not deem it necessary to define this concept and opt for either identifying and naming different existent emotions or simply stating that emotions are affective states (e.g. Dawkins 2000; Mellor 2012; Wilkins et al. 2015). 
We acknowledge that in animal social communication many messages serve to alert the communication partner about the emotional condition of the signalling individual and may thus be considered as serving an emotive function (Sebeok 1972: 73). There are also other contemporary authors who claim that emotions probably have a connection with majority of animal behavioural messages such as aggression, fear, affiliation, etc. (Snowdon 2003). However, there still is no commonly agreed upon definition of 'emotion' and the proposed definitions vary greatly between disciplines. It is clear that defining emotions is not an easy task, because "[...] on the one hand, they seem self-evident and obvious when examined introspectively; on the other hand, they have been extremely difficult to define in objective scientific terms" (Anderson, Adolph 2014: 187). In addition, in the relevant scientific literature, there seems to be a confusion between relatively close concepts, such as 'emotions', 'affects', 'feelings', e.g. primary affects (Tomkins, McCarter 1964) include six basic emotions (e.g. Ekman 1992, 1999). We are not the first ones to try and delineate the meaning of "emotion" (see e.g. Bekoff 2000; Russell 2003; Ott 2017; Anderson, Adolph 2014). A relatively recent theoretical overview (Ott 2017) distinguishes two main perspectives on dealing with emotions, where one of them is concerned with humanities and philosophy and the other perspective is occupied with psychology and neuroscience ${ }^{1}$. The Darwinian tradition is rather reflected in the latter, together with later developments by Ekman (e.g. 2006), Feldman Barrett (2011), Damasio and Carvalho (2013), Tomkins (Tomkins, McCarter 1964), and Panksepp (e.g. 1998). ${ }^{2}$

Finding a new definition for 'emotion' falls beyond the scope of this article, but we would like to continue our analysis with more clarity. We analyse mainly those instances which are compatible with Darwin's general treatment of emotions. This means that we are satisfied with the characterization of emotion as offered by Anderson and Adolph (2014), who proposed that emotions (caused by internal or external stimuli) cause several responses simultaneously (e.g. observed behaviour, cognitive changes, somatic responses, and others) that include external and internal feedback elements for the animal. This description is sufficient for our endeavour to discuss antithetical expressions of emotions in animals, i.e. it is applicable in an interspecific manner (i.e. suitable for analysing also other species besides humans) and the description includes the expressive nature of emotion (i.e. not simply a 'private sensation' that remains only in the recognition of the individual). We will add on our part, that the expression of an emotion, as Darwin most often viewed it, has a communicative function (i.e. it has a social

1 The author also tackles a third direction, which pursues to unite the two.

2 However, some of these authors are rather human-centred when dealing with emotions. 
dimension), ${ }^{3}$ and we will limit (most of our examples and analysis) to instances that could also be considered in the framework of the principle of antithesis.

It should be noted that Darwin took it for granted that animals have emotions, such as rage, astonishment, terror, joy, anger, etc. He even stated that in "[...] animals we see the same principle of pleasure derived from contact in association with love" (Darwin 1872: 215). Similarly, a hundred years later, Lorenz believed animals to be capable of love and accompanying feelings, such as jealousy. Lorenz believed that animal emotions were analogous to human feelings:

When we speak of falling in love, of friendship, of personal enmity or of jealousy in these or other animals, we are not guilty of anthropomorphism. These terms refer to functionally determined concepts, just as do the terms legs, wings, eyes, and the names used for other bodily structures that have evolved independently in different phyla of animals. (Lorenz 1981: 91)

We acknowledge that someone researching animal emotions might run into difficulties when trying to pinpoint some exact emotions (e.g. hope, pride, pity, etc.) for some species with relatively simple umwelten, but succeed with species with more complex umwelten. For example, already in the 1930s ethologists used the term 'boredom' to describe mammals' and birds' behaviour in the context of the zoo (see e.g. Burn 2017). In the case of cartoon characters as they are often anthropomorphized, projected emotions can be pinpointed more exactly as they often parallel human emotions.

Darwin also recognized the importance of the emotive function of emotions, i.e. "[w]ith social animals, the power of intercommunication between the members of the same community, - and with other species, between the opposite sexes, as well as between the young and the old, - is of the highest importance to them" (Darwin 1872: 60). In addition, emotions can also be seen as an organizing principle of social communication in animals (Kull 2018). With highly social animals it is essential that the expressions of emotions (or any behaviour, for that matter) are interpreted by the communication partner in the way intended to avoid mistakes in communication. Understanding the emotions of others is closely tied to the capacity of empathy, which should increase the cooperation between conspecifics (Kull 2018). This, however, presupposes that emotions are indeed correctly understood. The prevention of mistakes and reduction of ambiguity might be considered the reason why some of the expressions of emotion

3 This view has also gained support from other authors, who similarly state that certain behavioural expressions are not signs of emotions unless this behaviour is necessary for social communication (Feldman Barrett 2011). 
are distinctive in their form (Morris 1957) and emotions of opposite valence, i.e. negative versus positive, may in some cases also take opposite forms. This is also evident in semiotic enquiries, where the oppositional forces of attraction and repulsion, as related to emotions of fear and anger in the case of fight or flight response, are seen as leading from biosemiosis to psychosemiosis (Nöth 1994: 53). So, valence is one of the defining aspects of emotions (Russell 2003) that also prove to be important when discussing the principle of antithesis.

\section{The principle of antithesis in animal communication}

As stated in the introduction, Darwin regards the principle of antithesis to be based on opposition. To elaborate, from his description it is evident that antithesis is synonymous with binary opposition, an idea that has found support in semiotics, where the 'biopolarity' (i.e. the oppositional character of spatial movement of animals), or the oppositional nature of emotions, is discussed (e.g. Nöth 1994), although no reference to Darwin is made.

It is obvious that antithesis is a purely descriptive mechanism. This means that it does not have a self-reflexive character for the animal expressing oneself, i.e. we do not expect the animals to have any kind of perception of diametrically opposite emotions. Clearly, Darwin did not consider antithetical expressions to be part of animal's 'intended' behaviour either, stating that he did not believe that his " [...] dog voluntarily put on his dejected attitude and 'hot-house face,' which formed so complete a contrast to his previous cheerful attitude and whole bearing" (Darwin 1872: 67). This is not to claim, though, that binary oppositions of this type have no place as an analytical tool in characterizing animal behaviour and communication. We have established that there are some oppositional 'roots' of animal emotions, but there is no need to impose the necessity of self-reflection.

The principle of antithesis as an analytical tool is attractive, but it does have its imperfections, e.g. Darwin's examples of antithesis are primarily instances which allow for the animal's whole bearing to reverse. We need to stress that it is certain that often animal emotions cannot be considered as belonging to extremities, e.g. the dog described by Darwin (1872: 57-60) can sometimes be a little excited about going for a walk and sometimes very excited. So, the second defining aspect of emotions, besides valence is intensity (Russell 2003), sometimes also called gradedness (Nöth 1994). Thus, animals' (including humans') emotions are rather fluid, flexible and dynamic. Animals' expressions of emotions tend to fall more to the extremes in intense situations, e.g. "[...] we must remember that the capacity of maximum movement of animals in a balanced mental state is far less than that 
which occurs under conditions of extreme excitement, and in exceptional instances" (Hediger 1964[1950]: 53). Thus, the intensity of an emotion is context-dependent. The extreme expressions of emotions in a social context can be seen as imparting an important message that is unambiguous, attention-grasping, and fast, e.g. intense aggression by attack or a mating-call induced by high state of arousal.

Darwin's antithesis principle has also been criticized for having been used in instances that would better be explained by a more universal approach "[...] of pleasure sought or pain avoided" (Bruce 1883: 615), i.e. according to only the valence of the emotion. Indeed, if we reconsider Darwin's own examples about the aggressive (or angry) and loving (or joyful) dog, it is clear that these emotions, although expressed in ways that could be seen as opposites, are not opposing according to more contemporary and widely accepted wheel of emotions (Plutchik 1980). The opposite of anger or aggression is fear. However, it is true that the valences of the emotions that Darwin regarded, are exactly the opposites, with aggression or anger having a very clear negative valence and affective or joyful feelings having an unmistakable positive valence. This leads us to side with the developments in animal studies which re-emphasize that valence and intensity or degree of arousal are extremely important in animal emotion research (Mendl et al. 2010), but we also acknowledge that relying only on valence and intensity in any animal behaviour analysis would be oversimplifying the emotional variety exhibited by different species. Also, a series of problems arise when describing the expressions as indicative of a concrete emotion, which requires, as we have also stated, an adequate knowledge of ethology in order to pinpoint an exact emotion to a behaviour (Campbell 1997).

With the development of ethology and studies in animal communication, it is understandable that not everyone shares Darwin's views. However, there are also authors who strongly support Darwin's approach, claiming that even today his findings serve as a model for studying emotional expressions; that his principle of antithesis is well applicable to examine the expression of fear and threat (in both the vocal and visual modalities) in several species (Snowdon 2003); that the principle of antithesis is promising and deserves more attention than it has received since Darwin first proposed it (Parkinson 2005). Nevertheless, antithesis has not been systematically researched - there are only brief mentions of it from the second half of last century; nor have there been attempts to test its relevance (Thierry 2010) ${ }^{4}$. Still, Darwin was successful in inspiring the study of emotion in humans. His ideas were the basis for Ekman's creation of the typology of six

4 Thierry (2010) also states that Darwin's ideas about the expressions of emotions did not have substantial influence on the biology of behaviour. 
basic emotions, which are largely thought to be universal (Ekman 1992, 2006) ${ }^{5}$. Facial expressions, as supported by the basic emotions, have been relatively well studied in humans (e.g. Brinke et al. 2012; Ekman 2006; Parkinson 2005) but attempts have also been made to study them in other primates (e.g. Kanazawa 1996; Chevalier-Skolnikoff 2006; Waller, Micheletta 2013). We would like to reiterate that the approach of considering only certain aspects of communication (i.e. the appearance of the face) does not coincide with Darwin's approach of using multimodal ways of communication. The reduction of emotional expressions to only the face - regardless of the prevalent utilization of the visual communication channel by humans - diminishes the general appeal that was present in Darwin's study. The same idea is echoed elsewhere: "[...] one value of studying a variety of nonhuman animals is to emphasize the diversity of modalities of affective communication available (such as olfactory signals that have received little attention in human studies)" (Snowdon 2003: 463). This issue was also addressed by Hediger (1968), who has provided an extensive list of ways and channels for animal expression, including instances of expression of emotion.

We have discussed the possible applicability of the principle of antithesis in animals; however, we must acknowledge that the principle of antithesis in animal expressions of emotions is highly conditional, i.e. conclusions as to what extent the principle of antithesis is applicable depend on the species, concrete emotions and our knowledge of the animal, population or species. We are confident in stating that since the (possible) expression of antithetical emotions serves a communicative function, it can mostly be present in social animals with complex umwelten that create complex social relations and need to express themselves in a manner that is directed at clarity and avoiding errors in communication and mutual understanding. We also believe that the antitheses exhibit themselves in cases where the valence of the emotional state is very clear (i.e. positive or negative) and also the intensity on the emotion is high as well.

We need to stress, once again, the difficulties between intra- and interspecies interpretation and recognition of emotions and thus emphasize the need for further studies in animal emotions. This also raises a question as to whether the communication of antithetical emotions is limited to interspecies communication, or if these expressions can be interpreted in the expressions of non-biological beings. With regard to animal characters the communicative function of emotions only holds true for the receiver, i.e. the human viewing the cartoon. Darwin's (1872) principles of habitation and action of the nervous system refer to the

5 However, there are some authors who disagree about the existence of basic emotions (Ortony, Turner 1990; Jack et al. 2012). 
anatomical stimuli and ingrained actions of the animal, these anatomical principles, while referred to in the design of characters (Su, Zhao 2011), are not present within animated characters. Thus, the intent of animators in "imitating life" is to create characters that evoke emotions in an audience (Dias, Paiva 2005). In doing so, the social dimension is distorted, i.e. humans (animators) express certain emotions through animal characters to other humans (viewers) (Buchanan 2007: 77). The emotive function not only regulates the social relations or encounters between the characters of the cartoon, but also between the character and the viewer (Bates 1994). Thus, the key point of the analysis at hand is not about the emotional expression or projected state of the character itself, but rather the audience's perception of these effective states, and whether these expressions present antithetical qualities, and, if so, what techniques are utilized to achieve this.

\section{The principles of animation}

In the development of the principles of animation, Disney animation paid particular attention to the capabilities that the medium afforded them:

An artist could represent the actual figure, if he chose, meticulously capturing its movements and actions. Or he could caricature it, satirize it, ridicule it. And he was not limited to mere actions; he could show emotions, feelings, even innermost fears. (Thomas, Johnston 2018: 16)

While it can be suggested that often the expression of emotion is at the heart of any art form, animation sought to codify this concept in conjunction with biological and scientific concepts. Disney's animators aimed to achieve this lifelike expression of emotions with their principles of animation. This ideology is highlighted by one of the principles, appeal, which refers to the quality of likeability of the character established through the combination of the other principles (Luhta, Roy 2012: 32). This does not mean appeal in the sense of being generally attractive, but rather the ability to evoke emotions in the audience in general. The appeal and emotive ability of a character is not limited to its design; rather, it is holistic in nature, including the character's body movement, facial expressions, voice, etc., which corresponds with Darwin's implicit multimodal approach to the expression of emotion (Darwin 1872).

The first proposed principle is squash and stretch. This is based on the idea that organisms made of living flesh show changes in shapes (squashing and stretching) along with corresponding muscle movements as a response to pressure and force (Thomas, Johnston 1981:48-52). When a force acts on a given object it is squashed, 
while an object that is moving or being pulled will be stretched. In the expression of status or sensation in humans we can see this idea of squash and stretch in a few forms, e.g. a person who is shocked or threatened in a situation may assume a more rigid body posture, while someone who is sad or afraid may take a droopier or curled up posture (Kwon, Lee 2011). Viewing this from a semiotic vantage point, we can note that

[...] spatial semiosis assigns preferential values to directions, such as the vertical and the horizontal. Furthermore, whenever signs are part of an oppositional paradigm, such as verbal opposites up vs. down, these can be graded (as in further up/down) and allow for a local tertium (as neither up, nor down). (Nöth 1994: 51)

Similarly, Darwin, when describing the principle of antithesis with the example of a dog, addresses this opposition in body posture, stating that when the dog has a "hostile frame of mind" in approaching a human, the dog

[...] walks upright and very stiffly; his head is slightly raised, or not much lowered; the tail is held erect and quite rigid; the hairs bristle, especially along the neck and back; the pricked ears are directed forwards, and the eyes have a fixed stare. (Darwin 1872: 50)

The dog may also growl and expose his teeth. However, when he is in an affectionate state the dog's

[...] whole bearing is reversed. Instead of walking upright, the body sinks downwards or even crouches, and is thrown into flexuous movements; his tail, instead of being held stiff and upright, is lowered and wagged from side to side; his hair instantly becomes smooth; his ears are depressed and drawn backwards, but not closely to the head; and his lips hang loosely. (Darwin 1872: 51)

Darwin describes, in a similar manner, a hostile and affective cat (Darwin 1872: 56-57). While a clear parallel can be seen from the principle, Thomas and Johnston also bring in their own explication of this idea in describing the emotive ability of a dog stating that: "[ $t]$ here is no doubt when a dog is ashamed, or proud or playful, or sad (or belligerent, sleepy, disgusted, indignant). He speaks with his whole body in both attitude and movement" (Thomas, Johnston 1981: 19).

While the general rigidity or looseness of posture play a role in the expression of emotion, both Darwin as well as Thomas and Johnston note the importance of the multimodality of expressions. In animation additional emphasis is placed on capturing the behavioural realism of actions, resulting in the principle of secondary action, which posits that no action is completed in isolation, but rather 
there are always secondary actions and movements accompanying a primary action (Thomas, Johnston 1981: 65). The addition of secondary actions seeks to increase the behavioural realism of characters (Luhta, Roy 2012: 22), so that sad characters would not simply cry, but may rub their eyes, tilt their heads down, or turn their backs. This principle again highlights the acknowledgement of the multimodality of expressions. In his discussion of the principle of action of the nervous system Darwin explains that, "[t]he facial and respiratory muscles, which will be apt to be first brought into action; then those of the upper extremities, next those of the lower, and finally those of the whole body" (Darwin 1872: 71). The principle of secondary action is additionally supported by follow through and overlapping action, which emphasizes that a given movement will in turn lead to subsequent movements, which add additional emphasis to the overall affective intent (Thomas, Johnston 1981: 53).

In this way, animators pay particular attention to the intensity and valence of an action, while these are also as relevant in the expressions of emotions in real animals. This becomes important as expressions that are rather slight in their intensity appear as quite difficult to read (Morris 1957), thus, the principle of antithesis plays a particularly important role for the contrast between emotions and expressive states needs to be apparent. Within animation emotional contrast is addressed through the principles of exaggeration, so "[...] if a character was to be sad, make him sadder; bright, make him brighter; worried, more worried; wilder, make him wilder" (Thomas, Johnston 1981: 66). If the gradedness of an emotion is somewhere in-between (e.g. neither pleased nor displeased but indifferent) animators would make it pleased or displeased, making the expression one of strong valence and pushing it to the end of the spectrum. For example, if a character were to receive a gift, they may be pleased and start smiling and pulling it closer to them, or if displeased, may frown and push it away. The emphasis on exaggerated movements once again highlights the emphasis on the valence of actions in animation, which in turn increases the polarity of antithetical expressions even more so than in that of a human or animal.

In conjunction with exaggeration, timing specifically addresses the length and speed of a given action (Thomas, Johnston 1981: 64-65). A dramatic movement or gesture may be slowed down or an action sped up to add intensity or to manipulate the expression of emotional content, e.g. a slowed-down movement could be seen as bored or experiencing a state of lethargy, while a similar movement made at a great speed could be seen as excited (Whitaker et al. 2009). In conjunction with timing, another principle in that of slow in and slow out points out that transitions from one movement or expression to another do not happen very rapidly and that the transition between expressions is important to avoid a mechanical 
movement (Thomas, Johnston 1981: 63). It has been shown that individuals interpret the emotional expression differently when viewing actions of the same movements at different speeds (Pollick et al. 2001). Humans have some control of the timing of their emotive expressions such as how a person who does not want to go somewhere may "drag their feet" in slowing down their natural pace, while an excited person may "pick up their feet" and move at a more rapid pace. The degree of control of timing in animation allows for more purposeful control of the perceived valence and thus increases the intensity of an expressed emotion (Unuma, Takeuchi 1991). In animals, the aspect of timing does not necessarily take the same form as it does in animal characters or humans but is rather represented as a state of arousal or intensity, e.g. female goats may wag their tail repeatedly in states of arousal (Haulenbeek, Katz 2011).

In examining the principles of animation, parallels with Darwin's principle of antithesis can be made. Though they do not mention Darwin specifically, Thomas and Johnston (1981) mention the influence of biological theories and echo similar discussion points as Darwin. In fact, animation may even place a larger emphasis on the concept of antithesis and the exaggeration and increased valence of emotive expression as "[...] the disregard of some of the traditional animation principles (such as exaggeration, squash and stretch...) could result in a lack of believability (i.e. the extent to which a character seems to be alive) in the character" (Beck 2011: 13). These principles seek to strengthen the valence of an emotional expression, which may have its roots in human culture and its tendencies to think in binary oppositions (e.g. good-bad, up-down, black-white, etc.; see also Nöth 1994). While we have drawn a theoretical connection and parallel between the principles of animation and the principle of antithesis in real animals, we need to discuss in more detail the role anthropomorphism plays in the expressions of animal characters.

\section{Anthropomorphism and emotions}

Anthropomorphism, as the attribution of human mental and behavioural states to other animals or objects, often has negative connotations (Horowitz, Bekoff 2007). We agree that one should be wary of anthropomorphism that is inconsiderate of the knowledge that we have of animal umwelten, but we also agree that anthropomorphism, in certain cases, may give us better understanding of phenomena that are difficult to comprehend and can be useful when it favours a biocentric view (see also Maran et al. 2016: 41-42; Martinelli 2010: 170). As pertaining to animal-based cartoon characters, one might initially be hesitant to 
call it 'anthropomorphism' and rather be tempted to refer to it as a metaphoric relation, i.e. the animal stands in as a substitute for human (Ingold 2000: 91). While a cartoon or a story may have a metaphoric intent behind it, it may become difficult to draw out the specific intention when characters are viewed in isolation. In this way, Disney's The Lion King ${ }^{6}$ may tell a coming of age story of an exiled child loosely based on Shakespeare's Hamlet (Gavin 1996) when viewed in entirety, but when viewing a clip of Simba in isolation this interpretation is lost. In the same way someone viewing a still of Simba may not see him as 'just a lion', as, while he does share some similarity in the form of a lion, his design rather draws from that of the rules of animation (and to a certain extent anthropomorphism) and not the principles of the animal world. While many characters may take a metaphorical or metonymical (the extension of a human) role (Ingold 2000: 91), the audience does not inherently engage with the media/characters as if they were metaphors and may even engage with characters as if they were real (Reeves, Nass 1996).

This disparity between the lack of a biological basis and the potential communicative functions of these characters requires that we establish an analytical framework. To do this we utilize a semiotic typology for the analysis of "artificial animals" by Dagmar Schmauks (2000). The proposed typology establishes three sign functions for artificial animals, such as animated characters: "[...] artificial animals may represent living animals, substitute them in specific contexts, or be intended as an improvement of nature" (Schmauks 2000: 309-310). This provides us with a foundation from which to examine the purpose and referential basis of a given character, so that we may better build upon the communicative intent of the character and establish whether the emotive expressions of the character are based on a human, an animal, or a species of hybrid nature, which will allow us to identify if a species specific of antithetical emotion is present.

Earlier in our discussion, we mention that the body plans of animals of the same class may express emotional states in disparate manners (Hediger 1964[1950]: 111-112). As to expressing emotions in other animals besides humans, it is important to stress that we perceive a distinction between attributing and recognizing emotions that are analogous to those expressed by humans. Again, Hediger has an excellent example of incorrectly attributing a meaning to an animal who is not actually expressing an emotion:

6 The Lion King 1994. Dir. Rob Minkoff, Roger Allers. Perf. James Earl Jones, Jeremy Irons, Jonathan Taylor Thomas. Walt Disney Pictures. 
The crocodiles, and their relatives, present the greatest difficulties to the observer. It is of course a completely mistaken and inadmissible anthropomorphism to say that these armoured lizards wear a constant smile on their faces, just because the corners of their mouths are turned upwards between their powerful jaws. (Hediger 1968: 149)

In order to examine animal characters who express similar emotional states but reference different species with limited phylogenetic similarity, we will return to The Lion King. Both Simba, who represents a lion, and Rafiki, who represents a baboon, are used to substitute a human, and we can note that they primarily utilize human expressions (i.e. human facial expression and voice). While some lion-like and baboon-like characteristics are retained, respectively, their emotional states are primarily expressed in very human ways, overriding communicative disparities the viewers might have had with their biological referent. Though the artform itself affords animators the ability to manipulate the design of a given character to aid the viewers in expressive comprehension, it is also important to note the importance of similar body plans in animals that allows for the understanding of expressed emotions in nature.

There are several instances in which animals belonging to different species, yet possessing similar body plans, have similar ways to express similar emotions. For example, Darwin observed the behaviour of tamed wolves and jackals in a zoological garden, who upon seeing their keeper began to "[...] jump about for joy, wag their tails, lower their ears, lick their master's hands, crouch down, and even throw themselves on the ground belly upwards" (Darwin 1872: 125). Thus, it is reasonable to assume the overlap between these canine umwelten is large enough to allow for the correct interpretation and avoidance of mistakes in the expression of (certain) emotions that may take place in interspecies communication. There are relatively recent studies that confirm the possibilities of recognizing emotional expressions across species, e.g. an experiment conducted with deer (Odocoileus virginianus and Odocoileus hemionus) found that deer mothers can recognize and will approach the source of distress calls elicited by newborns from other mammalian species e.g. seals (Neophoca cinerea and Arctocephalus tropicalis), marmots (Marmota flaviventris), humans (Homo sapiens), cats (Felis catus), and others (Lingle, Riede 2014). What is especially interesting is that although these species might be considered taxonomically and ecologically distant from the deer, the overlap in their umwelten proves to be enough for the correct interpretation of a given expression of emotion. However, the cry of an infant is an extreme example in the sense that this has a strong connection to urgency and is probably one of the most intense expressions of emotions found in the animal kingdom - the distress call of an infant may also be considered biologically more important to be 
recognized immediately than, for example, expressions of boredom or surprise. It is also important to note that in the case of animal characters the majority of them have similar body plans, e.g. four legs; an upright stance (i.e. 'human-like' bodies).

We would like to stress that the body plan similarity of biological animals belonging to the same class (e.g. mammals), which may happen as described above does not guarantee that emotional states are consequently expressed in a similar manner. Hediger (1964[1950]: 111-112) describes an instance that is excellent for illustrating how the differences in umwelten and thus, in communicative capabilities, may lead to miscommunication about the expressions of emotion. The anecdotal case describes how a red kangaroo and a stag of a similar size shared an enclosure, and any time the kangaroo sat up "[...] the stag would go for him, rearing itself right up on its hindquarters and thrashing the completely inoffensive kangaroo until he squatted down again on his haunches" (Hediger 1964[1950]: 112). From the point of view of the kangaroo's umwelt, sitting up does (most probably) not entail any expression of emotional state - it is just that the body plan of the kangaroo is such, that his/her front legs are unable to touch the ground in a sitting position. For the stag, however, the raised front legs are perceived as an expression of a mental state, which carries a negative emotional valence (e.g. an expression of an emotion indicating aggression or anger), requiring the immediate action of attack. This is a clear example that the information needed for social communication is misinterpreted in various instances of interspecies communication, stemming from the incompatibility of umwelten.

Similarly, we may assume that a puppy who is not accustomed to cats might misinterpret a cat's defensive posture combined with tail wagging as an emotion resembling joy or happiness. This situation will most probably result in the cat hissing and maybe even attacking the dog. However, it is widely acknowledged that learning from each other (e.g. from a mother or a peer) is essential, especially in social animals, and thus animals from different species can learn to identify each other's emotional cues correctly as is the case with cats and dogs that have been brought up in the same household. Additionally, there are cases in which animals from different populations of the same species express the same state of mind in different manners, e.g. langur monkeys in Northern and Southern India carry their tails arched over the back or looping backward, respectively, to communicate confidence (Sebeok 1990). From these examples we can conclude that the ability to communicate one's emotional state effectively presumes a code that is understood by both parties during communication, i.e. there must be shared meaning.

The examples of the kangaroo and the stag or the cat and the dog demonstrate the importance of correctly interpreting the expressions of emotions in different animals' umwelten. The same precaution is pertinent to those studying 
animal emotions; as "[e]xternally, very similar behaviours can be produced by fundamentally different internal mechanisms" (Kull 2018), which is why the whole context of a given communicational situation should be accounted for. Such carefulness in the approach should also be maintained when dealing with machines designed to imitate the emotional expressions of animals, for example a Roomba with a 'dog's tail' which can be wagged, raised, lowered, or straightened to refer to different emotions (Singh, Young 2012). This does not take into account that a dog uses his/her entire body, not just the tail, to express emotions, and that the dog actually has emotions as such to express. As a crude metaphor, it would be comprehensible if the Roomba was 'happy' once it has finished its work, and e.g. 'attentive' when waiting for work, but it remains elusive, why it should be 'angry', 'suspicious', 'anxious', or imitate any other kind of mental state accompanied by those positions of a dog tail. However, this animal-inspired robot serves as a good example of displaced zoomorphism (if zoomorphism is usually defined as animals considering humans to be their conspecifics (e.g. Hediger 1964[1950]: 164-165), which could be also viewed as the attribution of other species-specific characteristics to humans, then in this case it is manifested as attributing the characteristics of other animals to things). In the case of animated animal characters we are not only limited to the use of anthropomorphism, but zoomorphism is often incorporated by animators into retaining elements of the animal referent in the behavioural expression of the character. It then becomes of interest to explore the outcome of these mixed modalities in the emotional expression and examine in greater detail how antithesis is presented by animal characters. Below, we offer a case study looking at the expression of an animal character to examine the presence of antithesis within an applied context.

\section{Case study}

In order to investigate the presence of antithesis in animal characters we utilize a joint methodology. First, we classify the sign function of the animal (Schmauks 2000) so that we can better determine the communicative intent behind the animal character and explore from what perspective we should focus on the expressive elements of antithesis present (e.g. a more human antithesis, a more animal antithesis, or one of a hybrid nature). Then we describe the character using Thomas and Johnston's (1981: 537-547) format for analysing the emotive expression of a character, which has us first look at the overall design of a character and its elements before exploring how specific emotions are expressed. For the purposes of this analysis we will limit our focus more generally to the eight paired primary emotions offered by Plutchik (1980) in his wheel of emotions. 


\subsection{Typology}

The character analysed is Poppy the Hedgehog (Fig. 1), a supporting character in the children's animation Gigglebug. "The stories are set in the oh-so enchanted Greengown Forest, where Gigglebug meets his young animal friends, all dealing with growing up. The series is heartfelt, warm, and safe, and best of all, a bunch of giggles!" (Gigglebug Entertainment) ${ }^{7}$. We chose to analyse a character from this series as it is a currently produced series enjoying a growing popularity that uses hand-drawn frame-by-frame animation similar to the techniques used at the time when the principles of animation were developed. We chose this character based on our knowledge of and access to its biological referent, hedgehog. Poppy is described by the series creators as "[...] airy, dreamy, whimsical, excitable, innocent, and bursts into tears easily" (Gigglebug Entertainment). From this initial information we can determine that Poppy is a representation of a hedgehog used to substitute a human. The substitution in general is intended metaphorically (Ingold 2000: 91), as the characters in the show are rather meant to offer didactic lessons to young viewers. From this we could assume the likelihood of the presence of expressions that align with those of a human antithesis. Still, the general construction of the character should be reviewed to see what degree of anthropomorphism is utilized.

\section{GIGGLEBUG}

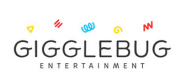

\section{0}
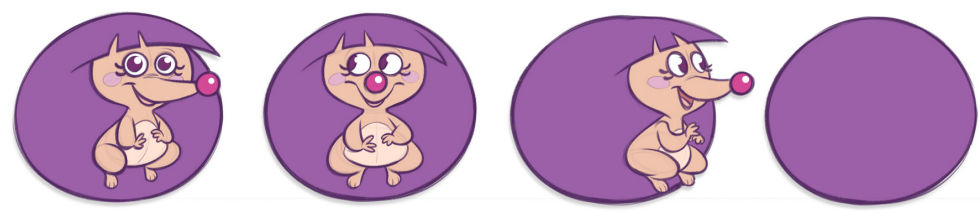

\section{POPPY THE HEDGEHOG}

Figure 1. Character sheet of Poppy the Hedgehog (Gigglebug Entertainment).

7 Gigglebug Entertainment. Gigglebug. Available at http://www.gigglebug.tv/ (Accessed 10 February 2018). 


\subsection{General construction}

A. Body/Movement: The design of Poppy is expressed as a circular silhouette composed of a more oblong, bipedal body with most of her frame made up of her 'hair', which represents the quills of a biological hedgehog. This hair takes a rounded, ball-like shape that also acts as a support that suspends her body when in place (see Fig. 1). Her hair will also squash or stretch along with her positioning and movements. In terms of general movement, she will switch from moving with her feet on the ground for larger movements and walking, but she will remain with her legs suspended for shorter movements. Her posture resembles more of a hedgehog placed on his/her back (Fig. 2) as compared to one on all fours. Overall, the representation can be identified as rather anthropomorphic, and bodily expressions would then be expected to rather align with those of a human.

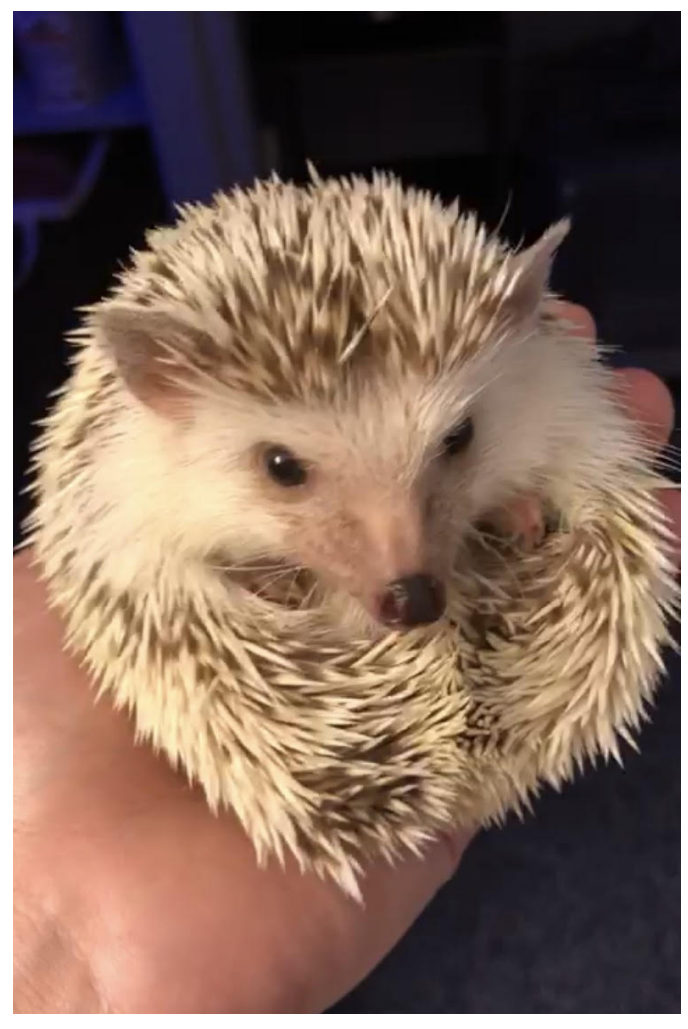

Figure 2. Tequila the hedgehog on his back (photo provided by Chase Tiffany). 
B. Voice: No direct human speech is used, but she utters a series of grunts, laughs, and sighs performed by a female voice actor, which accompany movements and gesticulations. This contrasts with that of a natural hedgehog who rather makes more sniffling snorts, or screeching sounds when under distress (Tynes 2010: 169-170). While stylized vocal expressions are used, we can see a clear usage of human expressions, and thus we can rule out the usage of a species-specific auditory antithesis.

The differences between the animal referent and the representation caused by the exclusion of biological hedgehog elements are likely meant to aid in the appeal and readability of the emotional states of the character. Since some species of hedgehogs have been domesticated, there is some public awareness of the expressive and sensational states of hedgehogs (Tynes 2010: 168). In this way we can generally clarify the typology of Poppy to be: (1) representing a hedgehog; (2) metaphorically substituting a human; and (3) improving upon the referent of a hedgehog through the heavy anthropomorphizing of the design and vocalizations. This means that in analysing the expressive gestures for the presence of antithesis, we primarily need to look at the emotional expressions of humans.

\subsection{Handling emotive expression}

In order to examine the emotive expressions used for the animation of Poppy, we reviewed a series of clips available on the Gigglebug Youtube Channel ${ }^{8}$. As instances of exact emotions are often context-specific (Anderson, Adolph 2014), we focused on instances in which the highest positive or negative valences were expressed, as these may result in the highest degree of emotional expression (Morris 1957). We focused on the following pairings: sadness-happiness; angerfear; surprise-anticipation; trust-disgust. No instances of perceived disgust could be found within the available clips, so an antithetical comparison was not available for trust. Descriptions of the physical and vocal elements of the character in each of these emotions are expressed in Table 1. It is also important to note that these expressions of emotion are multimodal in nature and that we have broken them down into separate pieces, which, when combined together, contribute to the whole bodily expression.

8 The youtube channel and analysed videos can be found here: https://www.youtube.com/ channel/UCBnDO41douBqsGK72rjppyQ. 
Table 1. Breakdown of emotive gestures in Poppy the Hedgehog.

\begin{tabular}{|c|c|c|c|c|c|c|c|}
\hline & $\begin{array}{l}\text { Squash or } \\
\text { stretch }\end{array}$ & $\begin{array}{l}\text { Limb } \\
\text { positioning }\end{array}$ & $\begin{array}{l}\text { Facial } \\
\text { expression }\end{array}$ & Voice & $\begin{array}{l}\text { Secondary } \\
\text { actions }\end{array}$ & $\begin{array}{l}\text { Timing/ } \\
\text { speed }\end{array}$ & Valence \\
\hline Anger & Stretch & $\begin{array}{l}\text { Arms } \\
\text { downward, } \\
\text { closed fist }\end{array}$ & $\begin{array}{l}\text { Eyes } \\
\text { squinted, } \\
\text { mouth } \\
\text { closed/lip } \\
\text { pout }\end{array}$ & $\begin{array}{l}\text { Low } \\
\text { pitched } \\
\text { grunt or } \\
\text { growl, } \\
\text { lower pitch }\end{array}$ & \begin{tabular}{|l} 
Stomp/ \\
downward \\
thrust
\end{tabular} & $\begin{array}{l}\text { Slowed } \\
\text { movement }\end{array}$ & Negative \\
\hline Fear & Squash & $\begin{array}{l}\text { Arms } \\
\text { brough to } \\
\text { chest, } \\
\text { tightened } \\
\text { body } \\
\text { posture }\end{array}$ & $\begin{array}{l}\text { Eyes } \\
\text { widened, } \\
\text { pupils } \\
\text { dilated }\end{array}$ & $\begin{array}{l}\text { Soft } \\
\text { whimper or } \\
\text { no sound }\end{array}$ & $\begin{array}{l}\text { Freezing or } \\
\text { stopping of } \\
\text { secondary } \\
\text { actions }\end{array}$ & $\begin{array}{l}\text { Slowed } \\
\text { movement }\end{array}$ & Negative \\
\hline Happiness & Stretch & $\begin{array}{l}\text { Arms open } \\
\text { outward, } \\
\text { head turned } \\
\text { upwards }\end{array}$ & $\begin{array}{l}\text { Eyes } \\
\text { closed or } \\
\text { squinting }\end{array}$ & $\begin{array}{l}\text { Laughter } \\
\text { sound, } \\
\text { higher } \\
\text { pitch }\end{array}$ & $\begin{array}{l}\text { Cheering, } \\
\text { or } \\
\text { accompany- } \\
\text { ing } \\
\text { laughing } \\
\text { gestures }\end{array}$ & $\begin{array}{l}\text { Quick to } \\
\text { normal } \\
\text { may } \\
\text { overlap } \\
\text { with } \\
\text { excitement }\end{array}$ & Positive \\
\hline Sadness & Squash & $\begin{array}{l}\text { Arms and } \\
\text { legs pulled } \\
\text { inwards }\end{array}$ & $\begin{array}{l}\text { Pupils } \\
\text { dilated, } \\
\text { frown }\end{array}$ & $\begin{array}{l}\text { Whimper } \\
\text { sounds }\end{array}$ & \begin{tabular}{|l|} 
Tears, \\
wiping \\
eyes, curl \\
up to more \\
ball shape*
\end{tabular} & $\begin{array}{l}\text { Slowed } \\
\text { movement }\end{array}$ & Negative \\
\hline Surprise & Stretch & $\begin{array}{l}\text { Arms and } \\
\text { legs both } \\
\text { spread } \\
\text { outward, } \\
\text { head } \\
\text { moved } \\
\text { backwards }\end{array}$ & $\begin{array}{l}\text { Pupils } \\
\text { contracted, } \\
\text { open moth }\end{array}$ & $\begin{array}{l}\text { Ingressive } \\
\text { gasp }\end{array}$ & No & $\begin{array}{l}\text { Quick } \\
\text { movement }\end{array}$ & $\begin{array}{l}\text { Positive/ } \\
\text { negative }\end{array}$ \\
\hline $\begin{array}{l}\text { Anti- } \\
\text { cipation }\end{array}$ & Squash & $\begin{array}{l}\text { Hunched } \\
\text { over, arms } \\
\text { brought } \\
\text { inwards }\end{array}$ & $\begin{array}{l}\text { Eyes more } \\
\text { dilated }\end{array}$ & \begin{tabular}{|l} 
Outward \\
hum or no \\
sound
\end{tabular} & $\begin{array}{l}\text { Movement } \\
\text { of hands }\end{array}$ & $\begin{array}{l}\text { Slowed } \\
\text { movement }\end{array}$ & $\begin{array}{l}\text { Positive/ } \\
\text { negative }\end{array}$ \\
\hline Trust & Squash & $\begin{array}{l}\text { Relaxed } \\
\text { arms put } \\
\text { together }\end{array}$ & $\begin{array}{l}\text { Eyes } \\
\text { closed, } \\
\text { small smile }\end{array}$ & No sound & No & $\begin{array}{l}\text { Normal } \\
\text { movement }\end{array}$ & Positive \\
\hline Disgust & NA & NA & NA & NA & NA & NA & NA \\
\hline
\end{tabular}

Overall, a wide degree of exaggeration was used in the expression of emotions, very few low-intensity expressions were present and rather a strong degree of intensity was utilized in the general expression of emotions. Follow through and 
overlapping actions were rather used to change the intensity or the valence of the character's emotive expression (see Fig. 3). Although in the case of trust, it tended to have a lower degree of intensity than the other emotions and had some overlap with expression of happiness.

In the pairs we saw opposite squash and stretch in the bodies and limbs: during the expression of surprise, happiness, and anger the body position of the character stretched, accompanied by outward extension of the limbs, while in the case of anger, the limbs were stretched downward. As to the proposed opposites of these emotions (fear, sadness, anticipation), we saw a degree of squashing and retraction of the limbs. In the same vein, a degree of antithesis was found in eye movements during expressions. When surprised, Poppy's eyes would open wide and her pupils would contract, whereas when experiencing anticipation, we saw narrowing of the eyes and dilation of the pupils. This degree of difference was less clear in case of other emotions, as in both sadness and happiness the character's eyes were closed in either laughter or tears, respectively. We identified no clear degree of difference in the character's voice based on the emotional pairings.

Concerning secondary actions, it is much less clear whether the secondary actions accompanying an emotional expression were antithetical in opposite expressions, but it was clear that the accompanying actions seemed to increase the intensity of the overall expression. In terms of the timing and speed of gestures and sounds in comparing happiness-sadness and surprise-anticipation, we could see that happiness and surprise tended to induce more rapid movements than sadness or anticipation. While some clear examples of antithesis were seen in the expression of the squash or stretch of the body and limbs of the character, a clear antithesis was less apparent for the other expressive elements we examined. It is important to emphasize the multimodal expression of emotion and the need to look at the intensity and valence of the overall expression. Regarding valence, we could see that some emotions take an overall opposite valence. For example, 'happiness' took a positive valence, while its paired opposites 'sadness' took a negative valence. In the instances of surprise-anticipation, it was more difficult to narrow down the particular valence of a given action as there were instances in which the anticipation-surprise took a positive valence (e.g. anticipation for something exciting would have a positive valence, while anticipation could also be negative in the case of anxiety). As mentioned above, the valence of an expression is very important, but it is not always enough to describe the complexity of an emotion. In the case of surprise-anticipation much of the valence is determined by an individual's response to the preceding or upcoming events, making these acts more as a transitional emotion of sorts. This once again highlights the importance of paying attention to the context of the overall expression. Returning to Darwin's 
examples where he contrasted an aggressive and a loving expression of the dog, the emotions themselves were not opposite, but their valences were exactly opposite. When viewing the expressions of anger and fear within the character, both had negative valences, so they would not be viewed as antithetical. Despite an initial analysis stemming from the principles of animation, the relation between valence and intensity in the multimodal expression of emotions in animated animal characters holds the same relationship as in that of animals.

\section{GIGGLEBUG}
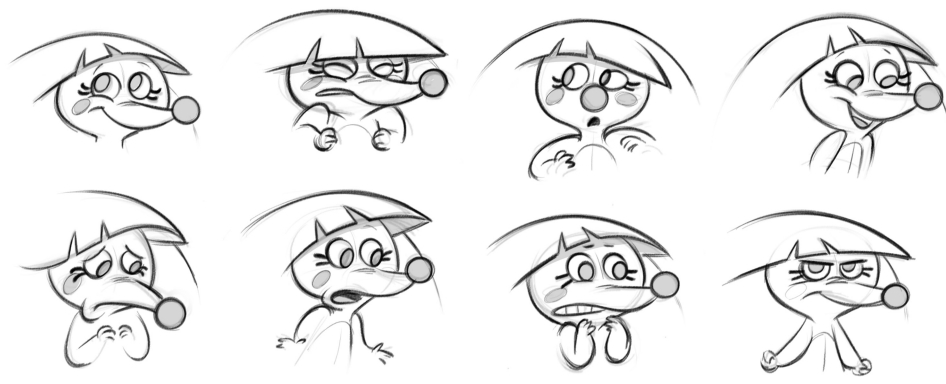

Figure 3. Character sheet of Poppy the Hedgehog with general expressions and gesticulations (Gigglebug Entertainment).

\section{Conclusion}

In order to discover what techniques are utilized to create an expressive function in animated characters, we established a parallel between Darwin's antithesis and the principles of animation. Antithetical forms used in the animation of characters play an important communicative function between animal cartoon characters and human viewers in particular, with animation placing additional emphasis on the valence and intensity of an action. The principles of animation play an important role in animation as a whole; thus, in our analysis of these principles through the lens of ethnological and anthropological zoosemiotics, we have established how these fundamental principles can be further analysed and expanded upon.

In drawing comparisons between the forms of animal characters and real animals we have additionally identified a few key points. When compared to the expression of antithetical expressions in animals, we can see that, in general, 
animation draws more on the expressive forms of humans as opposed to their biological referents (i.e. animal characters are largely anthropomorphic in their conception). However, it would be misguided to say that these characters draw solely on human expressions, as there is a degree of zoomorphism incorporated into the initial design and expression of these characters. We have also noted that in both the design of characters, as well as in real animals, a given individual's body plan plays an important role in aiding the communication of affective states. In the case of animals, there is a tendency for animals with more similar body plans to have a greater ease of interspecies communication, although even within a species with similar umwelten, different populations may still have miscommunications. In animal characters the key features of a character's design will often be manipulated to aid in overall communication; this is not limited to attributing a human voice to a character or making it bipedal, but also includes subtler changes, such as the placement of facial features and the elasticity, or rigidness, of the body and face during expressions.

Awareness of the biological concepts that govern emotional expression in real animals, as scrutinized in this article, can offer animators a starting point in the creation and analysis of their characters. In our analysis of Poppy the Hedgehog we offered a new approach for the analysis of animal characters, which combined zoosemiotic theories (Shmauks' typology of artificial animals, Uexküll's concept of umwelt, and Darwin's antithesis) with the character analysis approach offered by Thomas and Johnston. This joint approach affords a structure in which animators can better understand their innate decisions in character design. This could also offer a means for animators to identify the multimodal aspects of a character's expressions more effetively, so that these could be improved to make the character more engaging and expressive. It can be claimed that Darwin's concepts surrounding the principle of antithesis and the expression of emotion still hold ground in modern theoretical discourse and offer a fruitful connection and application within the field of animation and character design. ${ }^{9}$

\section{References}

Anderson, David J.; Adolph, Ralph 2014. A framework for studying emotion across species. Cell 157(1): 187-200.

Bates, Joseph 1994. The role of emotion in believable agents. Communication of the ACM 33(7): $122-125$.

9 This research is supported by research grants PRG314 "Semiotic fitting as a mechanism of biocultural diversity: Instability and sustainability in novel environments", and PUT1363 "Semiotics of multispecies environments: Agencies, meaning making and communication conflicts”. 
Beck, Aryel 2011. Perception of Emotional Body Language Displayed by Animated Characters. [PhD Thesis.] Portsmouth: University of Portsmouth.

Bekoff, Marc 2000. Animal emotions: Exploring passionate natures. BioScience 50(10): 861-870. Brinke, Leanne; Porter, Stephen; Baker, Alysha 2012. Darwin the detective: Observable facial muscle contractions reveal emotional high-stakes lies. Evolution and Human Behavior 33: 411-416.

Brockway, Robert W. 1989. The masks of Mickey Mouse: Symbol of a generation. The Journal of Popular Culture 22(4): 25-35.

Bruce, A. T. 1883. Emotional expression. The American Naturalist 17(6): 613-617.

Buchanan, Andrew 2007. Facial expressions for empathic communication of emotion in animated characters. In: Dobson, Nichola (ed.), Animation Studies: Animated Dialogues. Valencia: Society for Animation Studies, 75-83.

Burn, Charlotte C. 2017. Bestial boredom: A biological perspective on animal boredom and suggestions for its scientific investigation. Animal Behaviour 130: 141-151.

Campbell, Sue 1997. Emotion as an explanatory principle in early evolutionary theory. Studies in the History and Philosophy of Science 28(3): 453-73.

Chevalier-Skolnikoff, Suzanne 2006. Facial expressions of emotions in nonhuman primates. In: Ekman, Paul (ed.), Darwin and Facial Expression: A Century of Research in Review. Los Altos: Malor Books, 11-90.

Creed, Barbara 2009. Darwin's Screens: Evolutionary Aesthetics, Time and Sexual Display in the Cinema. Melbourne: Melbourne University Press.

Damasio, Antonio; Carvalho, Gil B. 2013. The nature of feelings: Evolutionary and neurobiological origins. Neuroscience 14(2): 143-152.

Darwin, Charles 1872. The Expression of the Emotions in Man and Animals. London: Murray.

Dawkins, Marian S. 2000. Animal minds and animal emotions. American Zoologist 40: 883-888.

Dias, João; Paiva, Anna 2005. Feeling and reasoning: A computational model for emotional characters. In: Bento, Carlos; Cardoso, Amilcar; Dias, Gael (eds.), Lecture Notes in Computer Science. (Vol. 3808). Berlin, Heidelberg: Springer, 127-140.

Ekman, Paul 1992. Are there basic emotions? Psychological Review 99(3): 550-553.

- 1999. Basic emotions. In: Dalgleish, Tim; Power, Mick J. (Eds.), Handbook of Cognition and Emotion. New York: John Wiley \& Sons Ltd., 45-60.

- (ed.) 2006. Darwin and Facial Expression: A Century of Research in Review. Los Altos: Malor Books.

Feldman Barrett, Lisa 2011. Was Darwin wrong about emotional expressions? Current Directions in Psychological Science 20(6): 400-406.

Gavin, Rosemarie 1996. The Lion King and Hamlet: A homecoming for the exiled child. The English Journal 85(3): 55-57.

Haulenbeek, Andrea; Katz, Larry 2011. Female tail wagging enhances sexual performance in male goats. Hormones and Behavior 60(3): 244-247.

Hediger, Heini 1964[1950]. Wild Animals in Captivity: An Outline of the Biology of Zoological Gardens. New York: Dover Publisher.

- 1968. The animal's expression. In: Hediger, Heini, The Psychology and Behaviour of Animals in Zoos and Circuses. New York: Dover Publications, 140-153.

Horowitz, Alexandra C.; Bekoff, Marc 2007. Naturalizing anthropomorphism: Behavioral prompts to our humanizing of animals. Anthrozoös 20(1): 23-35. 
Ingold, Tim 2000. The Perception of the Environment: Essays on Livelihood, Dwelling and Skill. London, New York: Routledge.

Jack, Rachael E.; Garrod, Oliver G. B.; Yu, Hui; Caldara, Roberto; Schyns Philippe G. 2012. Facial expressions of emotion are not culturally universal. PNAS 109(19): 7241-7244.

Kanazawa, So 1996. Recognition of facial expressions in a Japanese monkey (Macaca fuscata) and humans (Homo sapiens). Primates 37(1): 25-38.

Kull, Kalevi 2018. On the logic of animal umwelten: The animal subjective present and zoosemiotics of choice and learning. In: Marrone, Gianfranco; Mangano, Dario (eds.), Semiotics of Animals in Culture. [Zoosemiotics 2.0], 135-148.

Kwon, Ji-yong; Lee, In-Kwon 2011. The squash-and-stretch stylization for character motions. IEEE Transactions on Visualization and Computer Graphics 18: 488-500.

Lingle, Susan; Riede, Tobias 2014. Deer mothers are sensitive to infant distress vocalizations of diverse mammalian species. The American Naturalist 184(4): 510-522.

Lorenz, Konrad 1981. The Foundations of Ethology. New York: Springer Science.

Luhta, Etic; Roy, Kenny 2012. How to Cheat in MAYA 2010: Tools and Techniques for Character Animation. Waltman: Focal Press.

MacWilliams, Mark 2014. Japanese Visual Culture: Explorations in the World of Manga and Anime. London: Routledge.

Maran, Timo; Martinelli, Dario; Turovski, Aleksei 2011. Readings in zoosemiotics. In: Maran, Timo; Martinelli, Dario; Turovski, Aleksei (eds.), Readings in Zoosemiotics. (Semiotics, Communication and Cognition 8). Berlin: De Gruyter Mouton, 1-20.

Maran, Timo; Tønnessen, Morten; Tüür, Kadri; Magnus, Riin; Rattasepp, Silver; Mäekivi, Nelly 2016. Methodology of zoosemiotics: Concepts, categorisations, models. In: Maran, Timo; Tønnessen, Morten; Rattasepp, Silver (eds.), Animal Umwelten in a Changing World: Zoosemiotic Perspectives. (Tartu Semiotics Library 18.) Tartu: Tartu University Press, 29-50.

Martinelli, Dario 2010. A Critical Companion to Zoosemiotics: People, Paths, Ideas (Biosemiotics 5). Berlin, New York: Springer.

Mellor, David J. 2012. Animal emotions, behaviour and the promotion of positive welfare states. New Zealand Veterinary Journal 60(1): 1-8.

Mendl, Michael; Burman, Oliver H. P.; Paul, Elizabeth S. 2010. An integrative and functional framework for the study of animal emotion and mood. Proceedings of the Royal Society B: Biological Sciences 277: 2895-2904.

Morris, Desmond 1957. "Typical intensity" and its relation to the problem of ritualisation. Behaviour 11(1): 1-12.

Nöth, Winfried 1994. Opposition at the root of semiosis. In: Nöth, Winfried (ed.), Origins of Semiosis: Sign Evolution in Nature and Culture. Berlin: Mouton de Gruyter, 37-60.

O’Neill, Rob 2008. Digital Character Development: Theory and Practice. Burlington: Morgan Kaufmann Publishers.

Ortony, Andrew; Turner, Terence J. 1990. What's basic about basic emotions? Psychological Review 97(3): 315-331.

Ott, Brian L. 2017. Affect in Critical Studies. Oxford Research Encyclopedias: Communication. Oxford: Oxford University Press, 1-25.

Panksepp, Jaak 1998. Affective Neuroscience: The Foundations of Human and Animal Emotions. New York: Oxford University Press. 
Parkinson, Brian 2005. Do facial movements express emotions or communicate motives? Personality and Social Psychology Review 9(4): 278-311.

Plutchik, Robert 1980. A general psychoevolutionary theory of emotion. In: Plutchik, Robert; Kellerman, Henry (eds.), Emotion: Theory, Research, and Experience I. Theories of Emotion. New York: Academic, 3-33.

Pollick, Frank E.; Paterson, Helena M.; Bruderlin, Armin; Sanford, Anthony J. 2001. Perceiving affect from arm movement. Cognition 82(2): 51-61.

Reeves, Bryon; Nass, Clifford 1996. The Media Equation: How People Treat Computers, Television and New Media Like Real People and Places. Cambridge: Cambridge University Press.

Russell, James A. 2003. Core affect and the psychological construction of emotion. Psychological Review 110: 145-172.

Sebeok, Thomas 1972. Animal communication. In: Sebeok, Thomas. Perspectives in Zoosemiotics. The Hague: Mouton, 63-83.

- 1990. “Talking” with animals: Zoosemiotics explained. In: Sebeok, Thomas. Essays in Zoosemiotics. Toronto: Toronto Semiotic Circle, 105-113.

Schmauks, Dagmar 2000. Teddy bears, tamagotchis, transgenic mice. Sign Systems Studies 28: 309-324.

Singh, Ashish; Young, James E. 2012. Animal-inspired human-robot interaction: A robotic tail for communicating state. In: Proceedings of the ACM/IEEE International Conference on Human-Robot Interaction, 237-238.

Snowdon, Charles T. 2003. Expressions of emotions in nonhuman animals. In: Davidson, Richard J.; Scherer, Klaus; Goldsmith, H. Hill (eds.), Handbook of Affective Sciences. Oxford: Oxford University Press, 457-480.

Steinberg, Marc 2014. Realism in animation media environment: Animation theory from Japan. In: Redrobe, Karen (ed.), Animating Film Theory. Durham: Duke University Press, 287-300.

Su, Haitao; Zhao, Vincent 2011. Alive Character Design: For Games, Animation and Film. Berkeley: Gingko Press.

Tynes, Valarie 2010. Hedgehogs. In: Valarie, Tynes (eds.), Behavior of Exotic Pets. Oxford: Wiley-Blackwell, 168-180.

Thierry, Bernard 2010. Darwin as a student of behavior. Comptes Rendus Biologies 333: 188196.

Thomas, Frank; Johnston, Ollie 1981. The Illusion of Life: Disney Animation. New York: Abbeville Press.

Tomkins, Silvan S.; McCarter, Robert 1964. What and where are the primary affects? Some evidence for a theory. Perceptual and Motor Skills 18(1): 119-158.

Uexküll, Jakob von 1982. The theory of meaning. Semiotica 42(1): 25-82.

- 1992. A stroll through the worlds of animals and men: A picture book of invisible worlds. Semiotica 89(4): 319-391.

Unuma, Munetoshi; Takeuchi, Ryozo 1991. Generation of human motion with emotion. In: Thalmann, Nadia; Thalmann, Daniel (eds.), Computer Animation '91. Tokyo: Springer, 77-88.

Waller, Bridget M.; Micheletta, Jérôme 2013. Facial expressions in nonhuman animals. Emotion Review 5(1): 54-59.

Whitaker, Harold; Halas, John; Sito, Tom 2009. Timing for Animation. Oxford: Elsevier.

Wilkins, Abbie M.; McCrae, Lucy S.; McBride, Anne E. 2015. Factors affecting the human attribution of emotions toward animals. Anthrozoös 28(3): 357-369. 


\section{Пересмотренный принцип антитезы Дарвина - зоосемиотический взгляд на выражение эмоций у животных и анимационных персонажей животных}

В анимации и дизайне персонажей мультфильмов аниматоры часто обращаются к биологическим теориям и наблюдению за актерами-людьми и животными, чтобы более точно воспроизвести движения и эмоции. Чарльз Дарвин считал принцип антитезы одним из принципов, отвечавших за выражение эмоций у животных. Как нам представляется, этот принцип антитезы имеет особое значение в развитии анимации. Пересматривая первоначальную идею Дарвина в контексте принципов анимации, сформулированных Томасом и Джонстоном, мы можем оценить ее применение и актуальность при выражении эмоций у мультипликационных животных. Статья концентрируется на эмотивной функции в социальной коммуникации животных, как это описано в зоосемиотике, принимая во внимание, что выражения персонажей животных направлены на зрителя мультфильма. Принцип антитезы как описательный инструмент помогает нам в рассмотрении разнообразия методов, используемых одновременно в аффективной коммуникации, и позволяет объяснить человеческие интерпретации антропоморфных и зооморфных проекций в поведении анимационных персонажей животных. Эта статья дает представление о возможной экспансии и переоценке принципов анимации, которые могут быть использованы аниматорами для создания более динамичных и выразительных анимационных персонажей животных.

\section{Darwini antitees - zoosemiootiline perspektiiv loomade ja joonisfilmi loomadetegelaste emotsioonide väljendamisele}

Joonisfilmide loomtegelaste animeerimisel ja disainimisel on animaatorid sageli kasutanud bioloogiliste teooriate uurimist ja inimeste ning loomade vaatlemist, et paremini tabada elu jäljendavaid liikumisi ja emotsioone. Charles Darwini antitees - üks põhimõtetest, mida ta pidas vastutavaks loomade emotsioonide väljendamise eest - näib olevat animatsioonis erilise tähtsusega. Käsitledes Darwini algset ideed Thomasi ja Johnstoni animatsioonipõhimõtete kontekstis, suudame hinnata selle rakendamist ja asjakohasust joonisfilmides kujutatud loomade emotsioonide väljendamisel. Artiklis keskendutakse loomade sotsiaalse kommunikatsiooni emotiivsele funktsioonile, nagu seda on kirjeldatud zoosemiootikas, ja võetakse ühtlasi arvesse, et joonisfilmide loomtegelaste väljendus on suunatud vaatajatele. Antiteesi kui kirjeldava tööriista põhimõte aitab meil võtta arvesse afektiivses kommunikatsioonis samaaegselt kasutatavate kanalite mitmekesisust. Samuti aitab antitees selgitada inimeste poolt antavaid tõlgendusi joonisfilmide loomategelaste käitumise antropomorfsetele ja zoomorfsetele mõõdetele. Artikkel pakub võimaluse defineerimata animatsioonipõhimõtete laiendamiseks ja ümberhindamiseks, mida animaatorid saavad kasutada dünaamilisemate ja väljendusrikkamate loomtegelaste loomisel joonisfilmides. 